\title{
The Dehra Dun and Saharanpur Herbaria.
}

$\mathrm{T}^{\mathrm{T}}$ E Saharanpur Botanic Garden, situated in the old North-Western Provinces, India, was at one time in the charge of the late Mr. J. E. Duthie, who was responsible for placing the herbarium of that place in an exceptional position. This herbarium was transferred later to the Forest Research Institute, Dehra Dun. Mr. Duthie left numerous manuseript notes on the herbarium, and with their aid, Mr. R. N. Parker, forest botanist, has published an account of "The Herbarium of the Forest Research Institute".*

Mr. Parker tells us: "The Herbarium of the Forest Research Institute is composed of two very unequal portions, the larger being the herbarium of the Botanical Department of Northern India, usually known as the Saharanpur Herbarium, which was transferred to Dehra Dun in 1908 and amalgamated with the herbarium of the Forest School. Nothing is now known of the relative sizes of the two herbaria. The present collection was estimated to contain 222,000 sheets on lst January 1929." This brings the existing position of the herbarium nearly up to date. But to many the chief interest of Mr. Parker's account will be found in the concise history he gives of the Saharanpur Botanic Garden, and the long line of distinguished botanists who had more or less connexion with it. To those who are acquainted with the botanical and, it may be added, the forestry history of India, such names as Govan, Wallich, Royle, Falconer, Helfer, Griffth, Hooker, Jameson, and J. L. Stewart will take them back to the earlier work accomplished in the first half of last century. For this reason it is proposed to glance briefly at some of the more important passages in this history of botany and the Botanic Gardens at Saharanpur, with which the name of Duthie (an excellent portrait of whom is reproduced in the Bulletin) will be for all time associated.

The Botanic Gardens were established in 1816 on the site of an old native garden, which was much enlarged at various times. The first superintendent was Dr. Govan, who collected plants mainly in what is now Sirmoor State in the Simla district. A part, if not the whole, of his collections were listed with others in Wallich's Catalogue. What became of the plants is unknown, but a collection of drawings was ultimately presented to Kew. Dr. Royle succeeded Govan in 1823, and the results of his collections were published by him after retirement in "Illustrations of the Botany of the Himalayan Mountains ", which appeared in parts during 1833-40. In this work, Royle describes the area he explored and refers to a herbarium of 3500 species. He took the bulk of this collection home with him, there being no facilities for housing it at Saharanpur. This herbarium after his death was actually sold, by auction in London, for $11 \mathrm{~s}$, and is believed to have gone to Russia! Royle, however, presented a set of his plants to the Linnean Society and many of his plants are now

* Forest Bulletin, No. 73: The Herbarium of the Forest Rescarch Institute. By R. N. Parker. Pp. iii +10 , (Calcutta : Government of India Central Publication Branch, 1931.) 5 annas ; $6 d$ at Kew, some having been sent to Hooker or Bentham and going to Kew with the herbaria of these botanists. That Dehra Dun to-day possesses some of Royle's plants is chiefly due to the fact that, in 1876, Duthie found some bundles of the former's plants at Saharanpur, which were preserved.

Owing to his medical duties (as station surgeon) Royle was unable to undertake any botanical tours for the first three and a half years of his tenure at Saharanpur, but from a letter he wrote, dated June 28, 1828, it appears that he explored part of the Siwaliks and the Dun plateau, went up to Mussoorie, where he established an experimental physic garden, and marched across to Simla and on to Kotgarh. In the following year he made a more extensive tour in this part of the Himalaya. Wallich was superintendent of the Calcutta Botanic Gardens, and in the previous year had made the first botanical visit to the great forests of the newly acquired Province of Tenasserim and made some considerable collections.

Dr. Falconer succeeded Royle in 1831. His collections were augmented by his adopting Royle's method of sending natives to accompany caravans into the interior of the mountains. These collections, with the exception of a few bundles found by Duthie with those of Royle, were sent to the India House, London. They are referred to by Hooker in the preface to the "Catalogue of the Plants distributed at the Royal Gardens, Kew, from the Herbaria of Griffith, Falconer and Helfer". Falconer was also a geologist and investigated the fossil Siwalik fauna. Both Helfer and Falconer followed in Wallich's footsteps and were sent to report upon, and collect in, the forests of the Tenasserim Province in 1838-39 and 1849 respectively, the unrestricted fellings in the teak of that region having begun seriously to alarm the Government and the Court of Directors.

Dr. Jameson followed Falconer in 1842, retiring in 1876 . He was not a botanist, but had the credit of establishing the tea industry in Northern India. During brief periods of leave, Dr. J. L. Stewart (first conservator of forests in the Punjab, 1864, and author of "Punjals Plants") officiated for him in 1861, and Dr. G. King, afterwards superintendent of the Royal Botanic Gardens, Calcutta, in 1868 .

Dr. Duthie arrived in Saharanpur in December 1876 as superintendent of the Botanic Gardens, which post he held until April 1, 1887, when he became director of the Botanical Department of Northern India; he was then able to devote his whole time to botanical work until he retired in December 1902. The position of affairs on Duthie taking over his charge is thus described by himself : " On my arrival in Saharanpur I found the Museum (erected in 1859) filled with miscellaneous collections including animals, mostly birds, as well as many kinds of vegetable products such as fibres, drugs, etc., and in one of the glass cases sundry articles used in the manufacture of tea were exhibited. Other cases contained various rock specimens, 
including some of Falconer's original specimens of the Siwalik fossil remains of animals. The herbarium, such as it was, occupied a very subordinate position of the Museum; for, as the specimens were unarranged, unmounted, and for the most part unnamed, the collection could not in that condition be considered of any practical use to the public. The material consisted mainly of specimens collected by natives employed by Dr. Jameson during his tours in connection with tea culture. There were also a few bundles of specimens collected by Royle and Falconer in various parts of North-West India and labelled in their own handwriting. These, however, were mere remnants and scraps of their original collections."

Reference to Mr. Parker's article must be made for a study of the methods by which Duthie grappled with the position and built up the magnificent herbarium, ultimately to prove so firm a foundation upon which the Dehra Dun Forest Research Institute could build.

Reference has been made to the Dehra Forest School Herbarium. This was started by $\mathrm{Mr}$. Gamble, who became director of the School in 1890 and held the position for some ten years. To start this collection, Gamble presented a set of his own duplicates collected in Bengal and Madras. $\mathrm{He}$ collected assiduously during his stay at Dehra and received many contributions from forest officers and others. Duthie also contributed, and the in- structors at the School, especially Upendra Nath Kanjilal and Birbal, collected many species of local trees and shrubs. Some private herbaria made by forest officers were also presented.

Mr. Parker details some interesting facts in connexion with the earlier collectors and their direct or indirect influence on the present herbarium at Dehra Dun. The names include Roxburgh, Wallich, Strachey, Winterbottom, Griffith, Helfer, Hooker fils, Thomson, Stocks, Dalzell (Bombay), Wight (South India), Thomson, Beddome (conservator of forests, Madras and Bombay), Falconer, and Jameson. Amongst later collectors are the names of Col. Davidson, R.E. (Kumaon), Dr. Aitcheson (Punjab and Afghanistan), Dr. Goodenough (collection received from Kew), Sir D. Brandis (greater part of herbarium received from Kew), Thwaites (Ceylon), Gamble, Lace (Punjab, Baluchistan, Burma), Sir H. Collett (Simla, NorthWest Frontier, and Upper Burma), C. B. Clarke, C. F. Elliott (conservator of forests, Punjab and North-West Frontier), A. V. Munro (conservator of forests, Hazara, Multan, Baluchistan), C. W. Hope (many ferns), W. Gollan (superintendent of the Botanic Gardens, Saharanpur, 1887-1904-many plants and mosses), W. A. Talbot (conservator of forests-Bombay plants), Cooke (College of Science, Poona), and Dr. Lisboa (grasses). The Herbarium also contains series of plants obtained by foreign exchanges.

\section{Intelligence and Fertility.*}

\section{By Dr. Shepherd Dawson.}

$\mathrm{I}^{\mathrm{N}}$ VESTIGATIONS have recently been carried out in Glasgow into the relationship between birth-rate and intelligence. Individual Binet tests were given to more than twelve hundred children of ages three to fourteen years, and the results of these tests have been correlated with the size of the family to which each child belonged. The population studied was slightly below average both socially and intellectually; among the fathers of the children there was a high proportion of labourers, and the average intelligence ratio of the children themselves was about ten per cent below the average of the general population.

Most previous investigations have been concerned with birth-rates only. In the present inquiry, information was collected also regarding fatalities and survivals; as regards the family to which a child belonged, there was a record of the number of children alive, the number of fatalities (ante-natal, natal, and post-natal), the ages of the children and the parents, and the number of years the latter had been married.

Correlations were calculated between the intelligence of the child and $(a)$ the number of surviving children in the family to which he belonged, $(b)$ the number born alive, $(c)$ the number of births, and $(d)$ the number of possible lives. The correlations were all negative and small, but significant,

* Substance of a paper read before Section $J$ (Psychology) of the British Association in London on Sept. 24.

No. 3249 , VoL. 129] that is, they showed a tendency for dull children to belong to larger families; they were slightly higher when only those families were considered in which the age of the mother was forty-five years or more, and the family presumably complete.

By dividing the children into three groups, 'bright', 'average', and 'dull', with intelligence ratios above 114, 114 to 85 , and below 85 (100 being the normal), it has been shown that the birthrate in the 'dull' group is about 50 per cent higher than in the 'bright', while in the 'average ' group it is about 35 per cent higher. The fatalities (antenatal, natal, and post-natal) are most numerous in the dullest families and fewest in the brightest; yet, in spite of this, the proportions of survivors at the time of the examination remained about the same ; there were about 50 per cent more 'dull' than 'bright', and about 40 per cent more 'average ' than 'bright'. In the completed families the differences were greater.

The dullest children obviously came from the largest families. If it be assumed, as is commonly done, that, on the whole, the intelligence of children is like that of their parents, then the dull parents have, on the whole, slightly more children than brighter parents.

The question how far these results are representative of what is happening in the population as a whole is clearly of importance. There is ground for thinking that in a group which contains a higher 